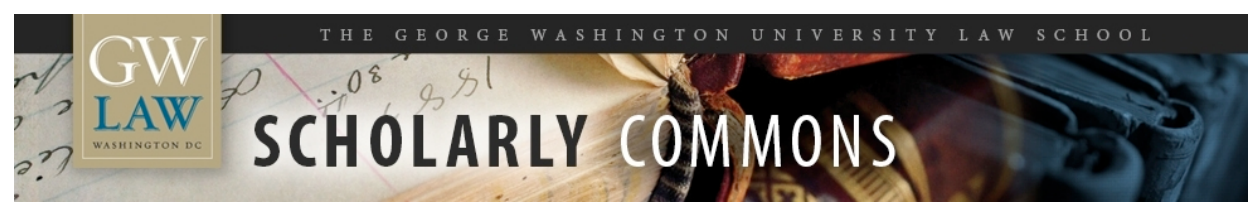

\title{
ENCYCLOPEDIA OF GENOCIDE AND CRIMES AGAINST HUMANITY
}

Dinah L. Shelton

George Washington University Law School, dshelton@law.gwu.edu

Follow this and additional works at: https://scholarship.law.gwu.edu/faculty_publications

Part of the Law Commons

\section{Recommended Citation}

ENCYCLOPEDIA OF GENOCIDE AND CRIMES AGAINST HUMANITY (Dinah L. Shelton ed., 2005).

This Book Part is brought to you for free and open access by the Faculty Scholarship at Scholarly Commons. It has been accepted for inclusion in GW Law Faculty Publications \& Other Works by an authorized administrator of Scholarly Commons. For more information, please contact spagel@law.gwu.edu. 


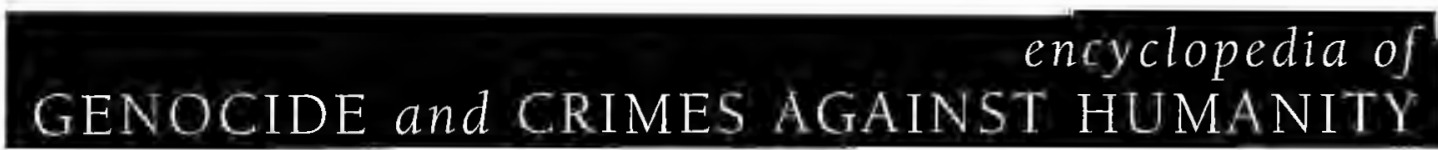

Dinah L. Shelton [ EDITOR IN CHIEF]

[A-H] 1

MACMILLAN REFERENCE USA

Arimprint of Thomson Gale, a part of The Thomson Corporation

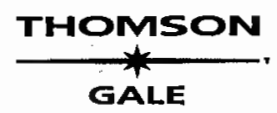




\section{preface}

The Encyclopedia of Genocide and Crimes Against Humanity tackles a difficult and often horrific subject. It looks at the worst, but also the best, of human behavior. The set is designed to offer the reader information about the barbarous acts that humans have perpetrated against each other throughout history, but also at the many and sometimes heroic efforts that have been made to understand, prevent, combat, and respond to such acts through law, politics, education, the arts, and sciences. The Encyclopedia is intended for general readers with a high school or college level education, although many professionals working in humanitarian and human rights organizations will find much here of use and interest to them.

World War II's Holocaust brought a new language into the world, including the word genocide. In response to the horrors of that event and other crimes committed in Europe and Asia, the international community conducted trials to prosecute and punish crimes against peace, crimes against humanity, and war crimes. These terms garnered better understanding as a result, although war crimes trials had precedents from earlier conflicts. After the Nuremberg and Tokyo trials, the first half of the twentieth century ended with states adopting an international treaty, the Convention for the Prosecution and Punishment of the Crime of Genocide, which outlawed efforts to destroy a people. Subsequent agreements have further identified and defined war crimes and crimes against humanity.

Genocide and crimes against humanity are not merely historical phenomena. It is estimated that more than 250 armed conflicts have occurred since World War II, with casualties numbering upwards of 170 million people. Some of these conflicts have been genocidal or involved war crimes and crimes against humanity, such as so-called ethnic cleansing and the use of rape as an instrument of war. Indeed, nearly all uses of armed force have involved issues discussed in the Encyclopedia. Massive human rights abuses committed by repressive regimes, such as kidnapping and disappearance of political opponents, massacres of minorities and systematic torture also fall within the rubric of crimes against humanity and, sadly, exist in contemporary society.

Efforts to prevent and respond to genocide and crimes against humanity are evident in the development of international criminal courts, peacekeeping, and humanitarian intervention by the United Nations, and the many educational programs and cinematic representations intended to raise public awareness of the problem. In addition, 
those countries throughout the world that are recovering from internal conflict or repression face the tasks of understanding the past, making appropriate reclress to survivors or victims of abuse, and ensuring the accountability of those responsible for the conmission of violent acts.

The topic is thus of vital importance and requires the involvement of a wide array of intellectual disciplines, professions, and skills. Historians, archaeologists, and anthropologists explain its global and temporal dimensions, identifying the past events that often led to current conflicts. Psychologists, philosophers, and theologians attempt to grapple with the reasons why human beings commit atrocities and seek to understand the responsive behavior of others, from collaboration through silence to active opposition. Lawyers and political scientists seek to construct institutions and legal structures that can impact human behavior, deterring genocide and crimes against humanity by designing effective and appropriate laws and punishment. Those in the arts educate and raise public awareness through film, music, painting, and writing. All of these disciplines appear in the Encyclopedia.

There are more than 350 entries in the Encyclopedia of Genocide and Crimes Against Humanity, arranged in alphabetical order for easy reference. In addition, an outline of contents at the beginning of volume one groups the entries thematically. The entries range in length from five hundred to five thousand words and concern historical and contemporary examples of genocide and crimes against humanity, individuals, groups, international institutions and law, theories and philosophy, prevention, prosecution, and cultural representations.

The set covers the ancient world to the present day and looks at all regions of the world. The editorial board affirmatively decided to include any event that has been publicly and reasonably debated as falling within the subject matter broadly viewed. Groups that have been the target of genocide or crimes against humanity are separately discussed, as are the known perpetrators. The various forms of reparation and redress available to victims and survivors are included, as are the courts and tribunals where the accused may be tried for their alleged offenses. Some entries describe the means used to incite public opinion toward hatred and genocidal acts, such as through advertising, radio broadcasts, and film. Short entries provide biographical information about key historical and contemporary figures, from Genghis Kahn to Simon Wiesenthal, while others describe important places such as Auschwitz and Srebrenica. Discussions of national and international policies during periods of genocide and crimes against humanity aim to provide readers with a wider perspective on the events reported.

The entries were written by experts, authorities in their respective fields. Like the topics they address, the authors come from countries throughout the world. As much as possible, the authors have used language that should be easily accessible to the public at large. The authors and editors have also attempted to be responsive to the sensitive nature of the topic, avoiding terms that may be offensive and noting where respected opinion is divided on the events or persons they describe. The result is a set of entries reflecting solid scholarship. A glossary of terms with which the reader might be unfamiliar appears at the end of the third volume, and each entry contains a bibliography to guide readers to further sources of information. Cross-references at the end of each entry refer to related topics.

The Encyclopedia contains historical images and contemporary photographs to illustrate the entries. Particularly for this topic, it is often difficult to visualize the reality of the events described. The editors have chosen the images carefully, not to shock but to provide further information and representation of the events and persons included.

At the end of the set, further material is included to assist the reader. In addition to the glossary, the concluding matter includes a filmography, primary source docu- 
ments, and a comprehensive subject index. The primary documents may be of particular interest to those undertaking research in this field. The documents consist of key legal instruments, such as the Convention for the Prosecution and Punishment of the Crime of Genocide and the Rome Statute of the International Criminal Court, as well as several important judicial decisions.

The editorial board and contributors have all benefited from the editorial assistance given by individuals at Macmillan Reference USA, in particular Hélène Potter, Justine Ciovacco, and Shawn Corridor. Their dedication to the project and infinite capacity for work inspired everyone. We express our thanks to them and to the others who contributed by suggesting authors, entries, and materials for the set.

Dinah L. Shelton 


\section{introduction}

Human beings have committed atrocities against each other, showed compassion and altruism, and both perpetrated and combated oppression for at least as long as recorded history. The archaeological record as well as recent forensic evidence reveal the burning of cities, massacres, enslavement, and fearsome tortures inflicted on captives. The preamble to the 1948 Convention against Genocide says, "at all periods of history genocide has inflicted great losses on humanity." It is also true for crimes against humanity. At the same time, religious and philosophical texts from all parts of the world contain variations on the "Golden Rule": treat others as you would be treated.

It is perhaps impossible to understand or reach conclusions about these competing strands of human history to determine whether human nature is innately good or intrinsically driven to violence and power. If it is equally impossible to document in detail the innumerable incidents of good and evil. At the same time, it is crucial to remember the dark periods when the worst traits in human beings have flourished, in order to think about and put into place means to prevent future abuses and to remember and mourn the millions of victims. The resisters and rescuers must be celebrated and the role of institutions studied, especially those that seek accountability and deny impunity for perpetrators.

These volumes are intended to be used not only as a tool to look into particular acts as well as agents of and opponents to genocide and crimes against humanity, but to understand from various angles the modes of expressions through which such acts are anticipated or ignored, articulated and covered up, understood and memorialized.

\section{Historical Overview}

Many events, persons, places, and devices that make up the historical record are included in the following three volumes. The aim is to present as factual a record as possible, noting where respected scholarship differs about the responsibility for or characterization of events. The reader may evaluate the evidence and reach his or her own conclusions. The Encyclopedia focuses on those acts that may fall within the definitions developed over the past century of crimes under international law: war crimes, genocide, and crimes against humanity. These labels attach to the most serious violations of the dignity and worth of each human being. Genocide itself is both a crime against humanity and the greatest of such crimes. It is appropriate to include in one encyclopedia all 
crimes against humanity while featuring genocide as thcir most prominent and cxtreme exprcssion. Further, by including all such crimes in the same encyclopedia, the understanding of their relationship becomes clearer.

At the time many of the events discussed herein took place, the protection of individuals from abuse had almost no role in international law and played little part in national or local law. Slavery was legal in most countries until the second half of the nineteenth century; colonial conquest and racial discrimination were prevalent and many indigenous groups were enslaved or annihilated by invaders. Torture and trial by ordeal were part of the criminal process by which it was assumed the truth would emerge. War was a means to gain wealth through looting and acquisition of territory. Rape, pillage, and destruction were the common features of armed conflict, with women and children considered a form of property to be taken along with works of art and other valuables

Traditional international law regulated the international relations of states. Individuals or groups of individuals were only indirectly regulated in respect to specific matters having international consequence, like diplomatic immunities, asylum. In addition, only states could be responsible for violations of international law, except in the case of pirates who were deemed "enemies of all mankind" (hostis humani) and subject to prosecution by any state which captured them.

By the second half of the nineteenth century, international efforts to combat some of the worst abuses committed or tolerated by states had emerged, with anti-slavery societies and laws for the conduct of war becoming part of the national and international orders. Humanitarian law sought to protect various categories of persons not engaged in combat: prisoners of war, shipwrecked, sick or wounded, and civilian populations of occupied territories. Persons in these categories were automatically placed in a legal relationship with the foreign state having power over them, without necessarily involving any role for the state of which they were nationals.

By the beginning of the twentieth century, the development of more rapid means of communication, through invention of the telephone and telegraph, meant the public could be informed more quickly and take notice of events happening in distant parts of the world. Travel was also made easier with the use of steam and later gasoline engines. As the world grew smaller, information about massacres and other widespread abuses became harder to conceal. Public opinion emerged as a factor in law and politics. Still, the plight of the Hereros in 1904-1907 and the massacre of the Armenians somewhat later produced little concrete action, perhaps because not enough information was made available to the public to avoid a debate about whether or not genocide was taking place could not be avoided.

Atrocities at the beginning of the twentieth century paled in comparison with the Holocaust of World War II in which the deliberate and systematic effort to clestroy entire groups of people because of their identity, rather than because of anything done by a particular individual, led to an unprecedented industrialization of murder. The postwar period vowed "Never Again" and took action to prosecute and punish those responsible for the worst abuses of the war. Yet, the national and international legal instruments designed to prevent genocide and crimes against humanity after World War II have not prevented these acts from continuing into the present. In 1994 in Rwanda, for example, an international military force was present and others available that might have stopped the genocide. Yet the atrocities continued without intervention until they had nearly run their course. In Cambodia (Kampuchea), as well, the world watched as mass killings gave rise to a new term: the killing fields. These events indicate that much greater understanding is necessary of the role of bystanders, as well as perpetrators and their victims. 


\section{Crimes and Punishment}

Atrocities committed throughout history were rarely punished because the perpetrators acted with the authority and protection of governments. Only in the midtwentieth century did the idea take hold that barbarous acts condoned by the governments where they took place could and should be punished by national or international courts.

Although the terms genocide and crimes against humanity are widely used in a colloquial sense to describe atrocities and mass killings, they also have a quite precise legal meaning. Indeed, fundamental principles of criminal law make it essential that the crimes be defined without ambiguity as a matter of fairness to all persons, who must be forewarned about the illegality of their behavior. The Encyclopedia retraces and explains, in depth, the evolution and terms of the body of laws in vigor now.

Many of the acts discussed in the Encyclopedia are considered to be crimes under international and national laws. Mechanisms of accountability seek to punish and deter perpetrators and provide redress for victims. While there are a few historical examples, accountability in both national and international law is relatively recent. Internationally, states could be held liable in some circumstances for the mistreatment of citizens of other states, but not of their own citizens. The laws of war allowed soldiers to be prosecuted for war crimes and examples of such trials date back to the late Middles Ages, but international law, generally, and treaties, specifically, demanded little in the way of accountability.

After World War I, the Allies created a commission which found that numerous acts had been committed in violation of established laws and customs of war and the elementary laws of humanity, but no international trials were held. A few individuals were tried by national courts.

At the end of World War II, the Allies brought before international tribunals the leaders and others involved in abuse of civilians and prisoners of war. Both crimes against humanity and genocide were first defined at this time, as Allied lawyers sought a basis for prosecutions of Nazi leaders. Because many of the Nazi atrocities, most specifically the persecution and extermination of the Jews and other groups within Germany, were carried out under cover of Nazi law in force at the time, it was necessary to root the war crimes in international law.

The creation of the courts at Nuremberg and Tokyo launched a half-century of advance in laws and procedures designed to restrain abuses of power. The trials emphasized that individuals, not the abstraction of states or governments, are responsible for violations of the law. The prosecutions of Nazi leaders provided the impetus for a more general recognition that such atrocities could be prosecuted by international courts, or by national courts operating on the basis of international law, even when they were condoned by the legal system of the country where they took place. It is presently widely accepted that those who order or commit such acts must be held accountable. The World War II trials helped ensure the development of the law and established the legitimacy of international criminal proceedings. The revelations about the Holocaust demanded invention of a new word to describe the scale and depth of what occurred: genocide, a term first proposed by Raphael Lemkin.

The Nuremberg Trial of the major Nazi war criminals established "crimes against humanity" as a general category of international offence, comprising forms of persecution, extermination, and deportation on racial, religious and political grounds. Following the trials, the newly created United Nations affirmed in 1946 the law and principles that formed the basis of the judgments and proceeded to draft the Convention to Prevent and Punish Genocide, adopted in 1948. The Convention defined genocide as the physical destruction of national, ethnic, racial, and religious groups, in whole or in part. 
Genocide was in essence an aggravated form of crime against lumanity. Whereas genocide involved the physical annihilation of the group, crimes against humanity covered a larger range of acts, subsumed under such terms as persecution. Genocide only covered groups defined by race, nationality, ethnicity or religion, whereas crimes against humanity extended to include political groups as well. But at the time they were devised in the mid-1940s, probably the most important difference was the fact that genocide could be committed in time of peace as well as during war. Crimes against humanity, though broader in scope in some respects, were also more limited, because they could only be carried out in time of armed conflict.

Another step in shifting the focus of international law from states to individuals came with the direct recognition of fundamental human rights and freedoms for all persons, independently of nationality or status under the jurisdiction of a given state. The United Nations and regional institutions in Europe, the Americas, and Africa proclaimed human rights and created international institutions and procedures where individuals claiming their rights had been violated could obtain a review of the matter. These were revolutionary developments in international law and relations, although they involved complaints brought against states and not against the individuals within the state responsible for the wrongs.

Immediately after the United Nations was founded, some members called for the establishment of a permanent international tribunal to try and punish those who commit international crimes. It took nearly half a century before the International Criminal Tribunal was in place. Indeed, for close to four decades from the 1950s, the idea was dormant. In the meantime, however, national courts became increasingly willing to prosecute crimes against humanity when committed in peacetime. In addition, when new atrocities appeared in various regions of the world-Cambodia, Yugoslavia and Rwanda-the UN responded by creating international criminal tribunals (for Yugoslavia and Rwanda) or trying to create such tribunals (Cambodia). Mixed national/ international tribunals also have been created or foreseen for Sierra Leone, East Timor, and perhaps Cambodia. By the 1980s it became clear that impunity, that is, the failure to hold individuals responsible for committing atrocities, was not only encouraging further human rights violations, but that it was also a violation of the rights of the victims themselves to redress. The international community proceeded with efforts to establish a permanent international criminal court, adopting the statute of the court in 1998. The Court was formally created in 2002.

Although people still refer to war crimes trials, most international prosecutions address crimes that can be committed in peacetime. Genocide and crimes against humanity are in many ways the counterpart to the concept of gross and systematic violations of human rights, also prohibited by international law. The terms genocide and crimes against humanity are used by criminal courts to hold individuals accountable, while the phrase gross and systematic violations of human rights usually applies to acts of governments. In fact, because the acts of governments or states are committed by individuals, the terms are merely different ways to designate the same phenomenon: atrocities committed against vulnerable groups, usually racial or ethnic minorities.

Genocide and crimes against humanity often involve the participation of large numbers of individuals, making criminal prosecution difficult for political and practical reasons. A search for alternative approaches to provide accountability short of a full trial has led to the creation of truth and reconciliation commissions, before which victims and perpetrators can confront each other and attempt to find ways to coexist in post-conflict societies. Thus, South Africa in the 1990 s decided not to prosecute most of those responsible for maintaining the apartheid regime, but their crimes were exposed in public and many perpetrators came forward to confess and seek forgiveness. 
Presently, the law and procedures range from national to international in the fields of human rights, humanitarian law, and criminal law. The substance of the law determines the list of crimes and the definitional elements that serve to identify when a crime has been committed.

Trials that seek to bring to justice perpetrators must consider the goals of individual accountability. First, accountability can be significant to the victims and to society as a whole as a matter of justice and partial repairing of harm done. Second, accountability may deter future violations by making clear the prospect of punishment for perpetrators and more generally serving the rule of law and strengthening of institutions. Third, accountability is society's expression of moral condemnation and may contribute to rehabilitation of the perpetrator.

Accountability mechanisms often must confront efforts of perpetrators to evade justice through self-amnesties or other measures that afford immunity from prosecution. Even persons committed to the rule of law and human rights sometimes argue that the transition from repression to a democratic regime demands reconciliation and forgiveness rather than prosecution. The various goals of accountability may not always be congruent. In most instances, however, human rights tribunals have rejected amnesties because they are viewed as a violation of international obligations and the rights of victims to redress. These decisions rest on the doctrine that states have a duty to prosecute and punish the most serious violations of human rights and humanitarian law or at least to provide some mechanism of accountability.

\section{Understanding}

Efforts to understand and thus prevent genocide and crimes against humanity are not limited to laws and tribunals. Various disciplines have been used to gain some insight into the causes and interpretations of genocide and crimes against humanity. They all require documentation. All are used to educate the public on different facets of such crimes.

\section{Modes of Memory, Commemoration, and Representation}

Memorials, various modes of artistic expressions in a multiplicity of styles and media are used by witnesses and scholars to represent, re-experience, commemorate, question, and comment upon atrocities and their victims. Dance, film, music, literature, photography, drama, and paintings serve to express what cannot be transmitted solely or completely by historical documentation. The Encyclopedia includes entries and illustrations that indicate and reflect upon the importance of artistic expressions to convey the experience, character, and various other facets of genocide and crimes against humanity.

\section{Those Involved}

In looking at issues of genocide and crimes against humanity it is not enough to recount events. The individuals involved, whether perpetrators, resisters, victims, rescuers or scholars have been the agents. Their deeds, their motives to the extent known, and their backgrounds can perhaps shed some light on the mystery of otherwise inexplicable brutality. The Encyclopedia thus includes general entries covering various categories of actors, such as perpetrators, victims, survivors, and rescuers, as well as individual biographies of persons involved in or witness to the events described. In addition, the psychological and sociological theories that seek to understand, explain, or at least classify behavior are included, as they may be useful in the future.

\section{The Editors}

The composition of the board of editors reflects the necessity of an interdisciplinary and international approach to the complex subjects addressed. 
Howard Adelman, a Visiting Professor at Princeton University, taught philosophy for over three decades at York University in Toronto, Canada, where he remains a Senior Scholar as well as a Senior Fellow of Massy College at the University of Toronto. He served as Director of the Center for Refugee Studies at York University between 1986 and 1993, and was editor of Refugc, Canada's periodical on refugees, for more than a decade. He has received numerous honors for his extensive scholarly work on conflict prevention, management, and resolution; refugees, humanitarian intervention, and genocide. His publications include War and Pcace in Zairc/Congo: Analyzing and Evaluating Intervention 1996-1997 (with Govind Rao, ed., 2003); The Path of a Genocidc: The Rwanda Crisis from Uganda to Zairc (with Astri Suhrke, ed., 1999); and chapters in edited volumes including "Bystanders to the Genocide in Rwanda: Explanations and Descriptions" in Genocide at the Tum of the Millenium (Sam Totten, ed., 2004); "Cultures of Violence" in Building Sustainable Peace (Andy Knight, ed., 2004); and "Ruvanda" (with Astri Suhrke) in the UN Security Council: From the Cold War to the 21 st Century (David Malone, ed., 2004).

Frank Chalk is a history professor and the Co-Director of the Montreal Institute for Genocide and Human Rights Studies at Concordia University in Montreal, Quebec, where he teaches undergraduate and graduate courses on the history and sociology of genocide, the Holocaust, and the history of U.S. foreign relations. He has served as President of the International Association of Genocide Scholars and is a past president of the Canadian Association of African Studies. He has taught as a Fulbright Fellow at the University of Ibadan, Nigeria, and has been a Fellow of the Center for Advanced Holocaust Studies of the U.S. Holocaust Memorial Museum, Washington, D.C. He is the co-author (with Kurt Jonassohn) of The History and Sociology of Genocide: Analyses and Case Strdies (1990). His most recent publications include chapters on "Hate Radio in Rwanda" (in The Path of a Genocide, ed. Howard Adelman and Astri Suhrke, 1999) and "Radio Broadcasting in the Incitement and Interdiction of Gross Violations of Human Rights, including Genocide" (in Genocide: Essays toward Understanding, Early Warning, and Prevention, ed. Roger Smith, 1999).

Alexandre Kiss is a citizen of France and Hungary. He is former director of the French National Center for Scientific Research and was a professor of law at the University of Strasbourg, France, where he was the director of the Center for Central and Eastern European Studies. He also served for ten years as the Secretary-General of the International Institute of Human Rights, and then became a Vice-President of the Institute. He is a member of the Hungarian Academy of Sciences and has been decorated by several governments and institutions. He has lectured throughout the world on issues of international law, litigated at the International Court of Justice, and is a member of the Permanent Court of Arbitration. His publications include the Répertoire de la Pratique Française en Matière de Droit International (7 volumes), Abus de Droit en Droit International, numerous works on international environmental law, and a seminal aricle on limitations in international human rights treaties.

William Schabas has been director of the Irish Centre for Human Rights at the National University of Ireland in Galway since 2000. For the decade before moving to Ireland he taught at the University of Quebec in Montreal, where he was Chair of the Department of Law for four years. He remains a member of the Quebec Bar. In 2002 Professor Schabas was appointed a member of the Truth and Reconciliation Commission of Sierra Leone. He has undertaken missions to investigate human rights violations and international crimes in Rwanda, Burundi, Sudan, Kosovo, and Chechnya and was a participant in the Rome Conference that drafted and adopted the Statute of the International Criminal Court. He has served with the Canadian delegation to international human rights bodies, including the UN Human Rights Commission. He has lectured extensively on humanitarian law and human rights law and is a renowned expert in international criminal law. His many publications include: The Abolition of the 
Death Penalty in International Law (3rd edition, 2002), Genocide in International Law (2000), and Introduction to the Intemational Criminal Court (2001). He is also editor of a two-volume set of essays on the Rome Statute of the International Criminal Court.

Dinah Shelton is professor of law at the George Washington University Law School in Washington D.C., where she teaches international law and the international protection of human rights. She has taught at other institutions in the United States and Europe, and lectured in Africa, Asia, and Latin America. She is a Counselor to the American Society of International Law and a member of the Board of Editors of the American Journal of International Law. She serves on the executive committees of numerous international human rights organizations and has been a consultant to most major international organizations concerned with human rights. Her publications on human rights include the prize-winning Protecting Human Rights in the Americas (with Thomas Buergenthal, 4th edition, 1995) as well as Human Rights in a Nutshell (with Thomas Buergenthal and David Stewart, 3rd edition, 2003), Remedies in International Human Rights Law (1999), and the edited volume Peace, Human Rights and International Criminal Law (2002). She has also published several books in the field of international environmental law with Alexandre Kiss, and is author of numerous articles on general international law.

\author{
Howard Adelman \\ Frank Chalk \\ Alexandre Kiss \\ William A. Schabas \\ Dinah L. Shelton
}

